\title{
The Annexation of Crimea:
}

\section{A Realist Look from the Energy Resources Perspective}

\author{
Javad Keypour $^{1}$ \\ TalTech Law School, \\ Tallinn University of Technology \\ Akadeemia tee 3 , \\ Tallinn 12618, Estonia \\ E-mail: jakeyp@taltech.ee \\ Ivar Hendla \\ University of Tampere \\ Kalevantie 4, \\ Tampere 33100, Finland \\ E-mail: ivar.hendla@riigikantselei.ee
}

Abstract: The article studies the role of energy resources in the annexation of Crimea by the Russian government. Russian justification that this action was taken to protect Russian ethnicity, as declared with the "referendum", can be challenged in the light of the realist balance of power concept. According to the research, Russia considered Ukraine's improving relations with the West as a threat and tried to eliminate it with preemptive action, in order to reestablish regional balance of power with the West. The article finds that the energy factor had a significant role in this consideration but in a subtractive approach. More precisely, there were no major incentives for Russia to capture the Black Sea resources intrinsically, but these reserves were recognized as part of the main Ukrainian economic empowerment plan, particularly on the EU's future energy market. Thus, Russia tried to block Ukraine's access to them in line with a wedge strategy. Hence, the annexation can be considered as one part of Russian energy policy towards the EU and Russia's goal to emasculate Ukraine's natural gas transit role by constructing new pipelines such as Nord Stream and Turkish Stream, as the other part.

1 Hereby, I would like to thank European Regional Development Fund's programme Dora Pluss activity 2.1 for the grant during my studies. 
The study exemplifies how Ukraine's strategic position has been significantly diminished from the energy perspective.

Keywords: balance of power, Black Sea energy resources, Crimea annexation, Russia, Ukraine

\section{Introduction}

When Putin came to power at the beginning of the 2000s, Russia had close cooperation with both the United States and NATO. The partnership was strengthened by aligned goals in war against terrorism. However, this trend drasticly changed shortly after NATO's expansion to the East continued to the Baltic States in 2004. Russia's perception of the accession process quickly created the notion that its national interests were jeopardized by NATO's expansion to the East (Kramer, 2002). On top of that, the color revolutions in the former Soviet republics started to undermine Russia's role in the whole region (Wilson, 2010). Amongst all these states, Ukraine holds a very special place for Russia from the cultural, political and economic perspective. Therefore, when it came to the 2013-2014 Ukraine crisis, Russia reacted harshly by the annexation of Crimea at the beginning of 2014.

The research aim of this article is to put Crimean energy resources under a microscope and discuss its role in the annexation from a subtractive approach, as the novelty of the research. The annexation of Crimea has certainly drawn the attention of many scholars already, so it would be incorrect to say that the event itself is underexplored. Generally, in previous research on the annexation of Crimea, the role of energy has been neglected entirely or trivialized to the level of the gas dispute between a gas owner, Russia, and the transit actor, Ukraine. This is the main knowledge gap that this article addresses.

The purpose of this study was to evaluate the role of energy resources in the annexation of Crimea. While often addressed as an energy transit state, Ukraine as a producer and contributer to European energy demand is often overlooked. This negligence is unjustified as Ukraine was known as one of the three largest unconventional gas resource owners in Europe and was promising to hold a significant position in the future energy supply of the continent (Weijermars, 2013). The post-crises changes in the possession of energy resources affects Europe's energy plans extensively, especially considering the fact that Europe 
is facing a decline in its domestic gas production until 2030 (Hall, 2018).

The researchers who have tried to give energy factor more attention in the annexation have not answered the principal question of how Russia, the biggest world natural gas owner (BP, 2017), would be tempted to seize the peninsula for some potential fields? As an example, Jeff D. Colgan and Thijs Van de Graaf (2017) show that the Ukraine crisis was not an "energy war" although energy did play a crucial role along other several dimensions. The authors believe the gas conflict between Russia and Ukraine is the most important factor in RussiaUkraine energy relationship. John Biersack and Shannon O'Lear (2014) believe the decision for annexation was backed by geopolitical and energy interests of the peninsula in Kremlin. Although the paper mentions the fact that Russia does not need Crimean resources thanks to its own giant gas reserves, it still gives a chance for these energy resources as a motivation for the annexation.

The main claim of the article is that Russia tried to hinder the EU's effort to take advantage of Ukrainian energy resources after Kyiv-EU agreement. Some researchers already assumed that Russia's aggression against Ukraine was raised to prevent it from joining to NATO (Mearsheimer, 2014). This research goes through the question of whether we can apply the same logic for Ukrainian energy resources. However, another point should be clarified at the beginning. The current research is not going to prove that energy interests have been the "main" reason nor "primary" motivation behind the annexation, instead, it tries to shed light on how the seizure of the peninsula has emasculated Ukraine in the future energy scene of Europe and assured Russian dominance on the European gas market. Thus, the research does not raise controversy against the idea, repeatedly stated by some scholars, that implies Russian military interests in the Black Sea as the main impetus of the Kremlin to seize Crimea (Schwartz, 2014; Karagiannis, 2014). Therefore, the research question is - what is the role of Ukrainian energy resources in Russian plans for annexation of Crimea?

This study employed theoretical thematic analysis since it is a flexible method appropriate for the problems demand a holistic methodology (Guest, MacQueen, \& Namey, 2012). Using data from diverse resources and multiple researchers' works increases the reliability of the method. Therefore, in the first step, data has been prepared to rely on both primary and secondary sources. In other words, while statistical energy documents have been studied as the primary sources, analytical and statistical reports, as well as books, research papers and journals have been studied as the secondary ones.

The structure of the paper is as follows. First, the findings of the current gas 
relation between Russia and Europe is investigated. In the discussion part, the Ukrainian plans to achieve energy independence and becoming a net exporter (and a significant energy provider for Europe) is discussed and next, the incentives of Russia for the annexation of Crimea are explained based on the findings and relying on the balance of power concept. Finally, the conclusion will come to find the answer to the research question.

\section{Results and findings}

Ukraine's role in the EU's natural gas market can be divided into two parts: the traditional one as the transit route for the gas flow from east to the west and the planned role that implies on a natural gas provider for the future of Europe.

\subsection{Ukraine's role in EU's gas demand: the transit route}

Although the first oil shock made the EU think about its 'energy security' at the beginning of 1974, the green continent has been dependent on external sources for more than half of its energy needs, and this share has been increasing in recent years. As is shown in Figure 1, EU imported more than 55\% of its consumed energy and more than $74 \%$ of its natural gas in 2017 .

Figure 1. Evolution of the EU energy dependency percentage (1990-2016)

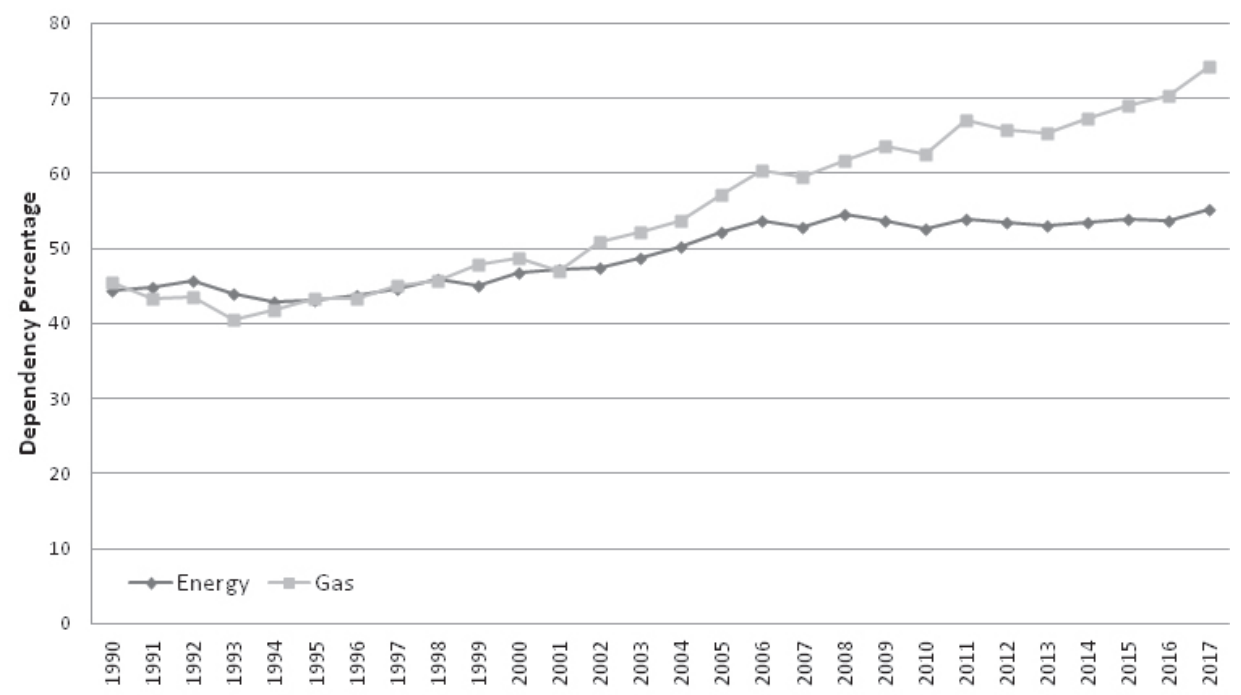

Source: Eurostat, 2019 
Russia has been a source of energy for the EU for a long time. This became particularly obvious for gas since the mid-1970s, when the building of natural gas pipelines was started from the Soviet Union toward the West. In 2017, Russia provided $35 \%$ of the total EU-28 supply (EIA, 2018).

Traditionally, Russian gas has flowed to the west via Ukraine; however, a conflict in Moscow-Kyiv energy relationship started to rise after the disintegration of the Soviet Union. In fact, since the collapse of the Soviet Union in 1991, Russia and Ukraine have struggled to address the problem of the changing conditions before and after the collapse of the Soviet Union. During the Soviet Union period, one country had combined significant state-owned gas reserves and a vast pipeline system stretching to the borders of Europe (Lockwood, 1993). However, in the post-Soviet era, one country controls gas supply (Russia), while the other one (Ukraine) both relies on that supply and has a significant influence on its delivery to important export customers. This resulted in two major conflicts in Russia-EU natural gas relations in 2006 and 2009 (Henderson, 2015). As a result, Europe considers dependency upon Russian gas as a threat also because of the Ukraine-Russia conflict in recent years.

According to a Russian energy diplomacy document, published by the government, "politicization in energy relationship between Russia and foreign countries" and "Russian export dependence on transit countries" are the two main problems of the country (IES, 2010). As the document points out Ukraine implicitly, Ukraine's role in transiting Russian gas to the west has declined from $85 \%$ in 2006 to $48 \%$ in 2017. This means that while in 2006 Ukraine transferred $128.5 \mathrm{bcm}$ out of 151.46 bcm, in 2017 it transferred $93 \mathrm{bcm}$ out of $194 \mathrm{bcm}$ (BP, 2017).

The declining trend of Russian gas export to the EU via Ukraine is likely to continue in the future. In April 2018, Alexei Miller, head of Russian gas giant Gazprom, declared that
Russian resource base has been moving northward and there won't be the same resources in the central gas transportation corridor as it was in the past. That's why a certain transit could still be in place, in the amount of 10-15 bcm per year, but the Ukrainian side has to explain the viability of the new transit contract. (Soldatkin, 2018)

Despite the fact that Miller did not give a time frame for the portrayed goal, it shows obviously how Ukraine's role in the gas transfer is falling.

Russia's plan to diminish Kyiv in the gas transmission is based on the construction of two main pipelines towards the EU: Nord Stream 2 and Turkish Stream. 
Some eastern EU Member States believe Nord Stream 2 to be a threat to their interests and, therefore, have tried to hinder the pipeline construction relying on a legal measure of the EU (Pirani \& Yafimava, 2016). This has been followed by proposing a revision to the Third Energy Package, the main existing antitrust legislation package in the EU (Talus, 2019). However, as Germany will be the main customer of Russian gas via Nord Stream 2, and due to the participation of giant energy companies like Gazprom, ENGIE, OMV, Royal Dutch Shell, Uniper, and Wintershall as the shareholders (Nord Stream 2, 2018) it seems to be a promising project. Elimination of Ukraine from the EU-Russia gas relation will not only deprive Kyiv of the transit revenue but also emasculates Ukrainian strategic place in this relation.

\subsection{Ukraine's role in EU's gas demand}

In addition to Russia's plan for curtailment of Kyiv's transit role, Moscow tends to affect Ukraine's plan for domestic gas production. In fact, Ukraine has been planning to optimize its efficiency in energy consumption while increasing its domestic production. As depicted in Figure 2, the Ukrainian energy intensity (units of required energy per unit of GDP) has been improving in the postSoviet era; however, it is still significantly higher than the EU average. In April 2018, Ukraine and EU signed a 50 million euro agreement to support energy efficiency projects which obviously shows the great potential of Ukraine to lower its energy waste (EEAS, 2018).

Figure 2. EU and Ukraine energy intensity, 1990-2015

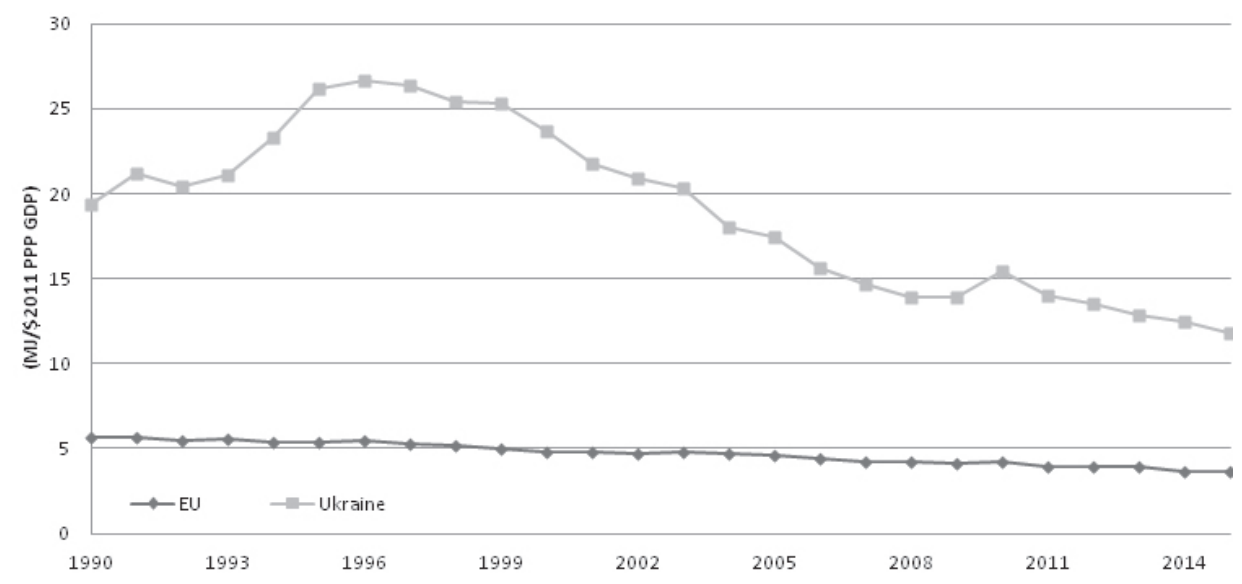

Source: The World Bank, n.d. 
Because of the decline in energy intensity and gas consumption, Ukraine has decreased its gas import during the last two decades, and it promises to cut its dependence on external sources (EIA, 2017). It is even predicted by Yuriy Vitrenko, the chief commercial officer of Naftogaz Ukraine that Ukraine will get rid of the dependence on Russian gas supplies from 2020 and become an exporter (Favasuli, 2017). Figure 3 shows how Ukraine has been decreasing its dependency on external gas sources during the last decades.

Figure 3. Ukraine's gas production, consumption, and import 1995-2016, bcma

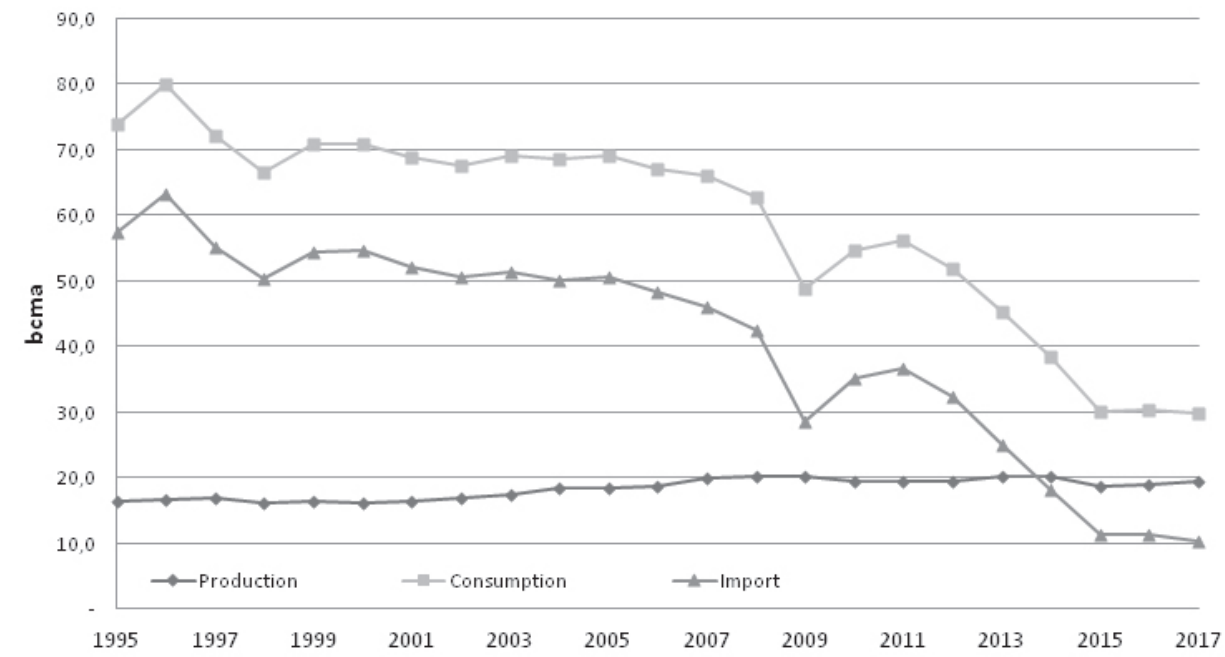

Source: BP, 2017

In addition to demand management, Ukraine's achievement of the position of a net exporter has been planned on promotion of domestic production, mainly unconventional sources in the Eastern Ukraine and the resources of the Black Sea. While unconventional gas resources, including shale gas and coal bed methane, are located in the east, particularly in Kharkiv and Donetsk, Black Sea resources in Crimean territorial water are classified as conventional ones.

An early estimate has already implied on the potential of resources in the Dnieper-Donets basin, the Donbas fold belt in Eastern Ukraine (Kabyshev et al., 1998). Energy Information Administration of the United States (EIA), estimated that $63.5 \mathrm{Tcf}$ of natural gas and 1.2 billion barrels of oil are technically recoverable from the Dnieper-Donets basin and has come to similar conclusions (EIA, 2015). This is worth more than 450 billion dollars at 70 dollars per barrel. 
Another recent study shows that amongst European countries, Poland, France, and Ukraine host the largest unconventional resources by estimations (Weijermars, 2013). EIA ranked Ukraine as the third shale gas resource owner in Europe (excluding Russia) as can be seen in Figure 4. The noteworthy point here is that while there are restricting rules and regulations in EU against shale gas activities (Tawonezvi, 2017), Ukraine is not an EU Member State and therefore can start production from unconventional resources without any legal bans.

Figure 4. Shale gas resources in Europe, trillion cubic feet (tcf)

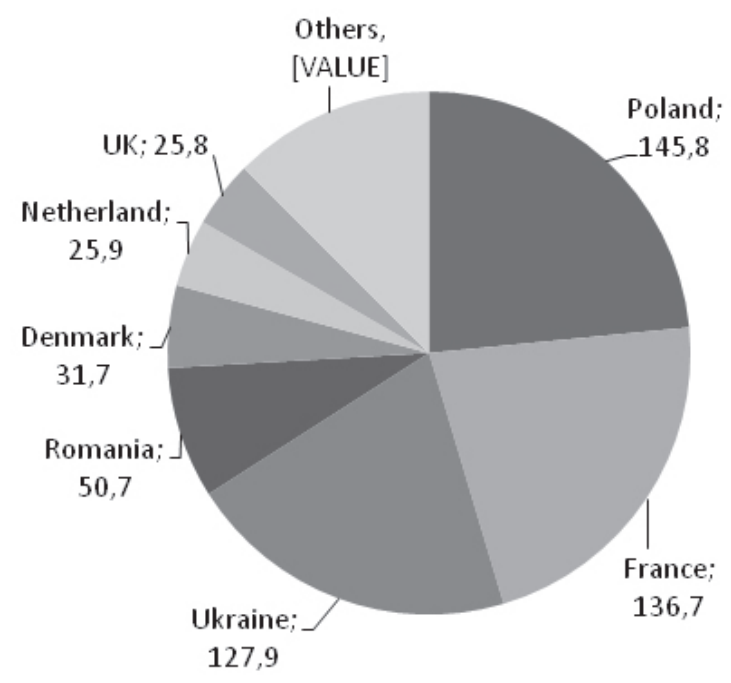

Source: EIA, 2015

When it comes to the Crimean energy resources, no unanimously accepted prognoses are available, as the exploration of the reserves by ExxonMobil was stopped after the annexation. However, former Russian Minister of Natural Resources and Ecology Sergei Donskoi announced that Crimean territory has 44 hydrocarbon fields, 7 gas condensate reservoirs, and 10 oil and 27 gas fields. Natural gas reserves of 165.3 billion cubic meters, 47 million tons of oil and 18.2 million tons of gas condensate. "Oil fields are not numerous in Crimea but natural gas resources are big enough for such a relatively small region. It has gas condensate reservoirs as well," he said (TASS, 2014). Ukrainian media last reported that Russia had seized some 7 billion cubic meters of natural gas from nine producing fields around Crimea since the annexation of the peninsula until April 2018 (UAWire, 2018). 
In November 2013, Ukraine signed a 10 billion dollar shale gas productionsharing agreement with Shell for exploration at Yuzivska in Eastern Ukraine in order to take advantage of its natural gas resources. Yuzivska was discovered in 2010 and, according to an optimistic scenario presented by the former Minister of Power Generation and Coal Mining of Ukraine Eduard Stavytsky, Kyiv could double production only owing to Yuzivska gas field (Stavytskyi, 2013). In another, more realistic scenario it was predicted that these two shale projects, Olesska field in the West and Yuzivska field in the East, would help Kyiv to reach an additional 11 to 16 billion cubic meters (bcm) of gas in five years' time (Polityuk \& Balmforth, 2013). A similar production plan was sketched for development of the Skifska block in the Black Sea by a consortium led by ExxonMobil (XOM.N) and Royal Dutch Shell (RDSa.L). It was planned to reach a production level of $5 \mathrm{bcma}$, according to Stavytskyi (Polityuk, 2012). These plans are now suspended due to the seizure of the peninsula by Russia. Figure 5 shows the location of the exploration blocks next to Crimea.

Figure 5. Crimea's oil and gas assets

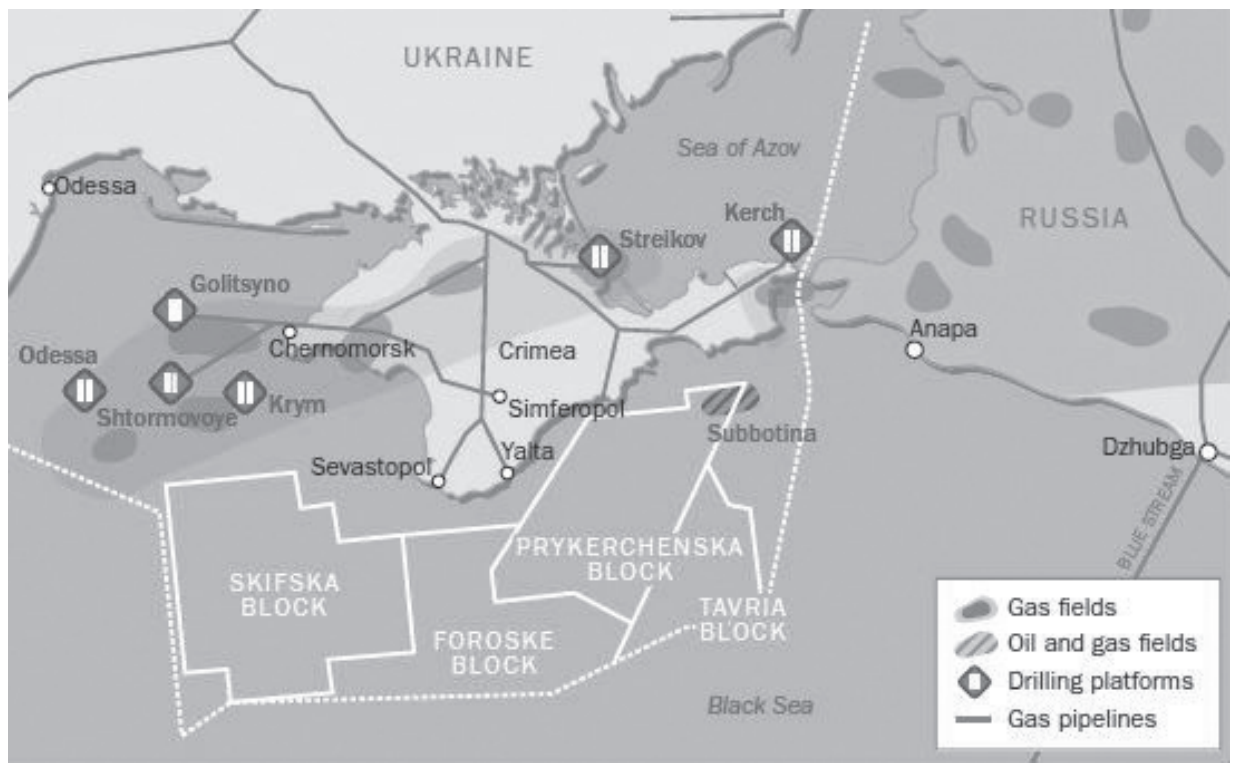

Source: Eurasian Business Briefing, 2016

It is also worth mentioning that according to the statistics, Ukraine had 600 $\mathrm{bcm}$ of conventional natural gas resources in 2014 (BP, 2017). This means that Crimea has more than a quarter of Ukrainian gas resources, assuming the accuracy of the statements of the former Russian Minister of Natural Resources 
and Ecology that Crimea had $165.3 \mathrm{bcm}$ gas resources in 2014. In addition to this fact, the unconventional gas resources of Ukraine in Dnieper-Donets are three times the amount of the whole conventional proved resources. The operation for developing the fields in Eastern Ukraine is also suspended now because of the crisis.

\section{Discussion and implications}

One of the main pillars of the neorealist school in international relations is the 'balance of power concept'. In principle, states are fundamentally concerned with their own survival, within the anarchic international system (Waltz, 1979). Therefore, states are inclined to act in a manner of self-interest and regard their own interests and hope for survival as paramount (Mearsheimer, 2001). States must also use all the means in order to survive or dominate, while domination is the guarantee of survival. Therefore, states tend to form alliances and weaken their opposition. (Waltz, 1979). The balance of power theory also implies that the increased power of one state occurs at the expense of others, which makes states cautious of each other because they do not wish to see others shift the balance of power in their own favor (Mearsheimer, 2001). According to Kenneth Waltz, states are compelled to preserve the current balance of power (Waltz, 1979) and just take actions when the balance is disturbed. In the context of the triangular relations between Russia, Ukraine and the West, we can see how the alignment of Ukraine and the West can be perceived as a clear and direct threat to the former regional balance, under which Ukraine was considered to be in the sphere of influence of Russia.

The balance of power concept is based on superpower behavior and focuses on the desire to dominate. Superpowers seek to maximize their share of global power using different measures, such as the economy, military, and diplomacy, to change the power balance in their own favor using whatever means they have at their disposal. Many realists have argued that all states would like to become hegemons and many scholars suggest that the US or the West in general achieved this status (Clark, 2009) triggering an initially candid, but gradually more and more open confrontation, as the rivals are compelled to take preemptive action to prevent the growth of the power gap (Astrov, 2011; Walt, 1985). The most obvious way to do that is to protect one's sphere of influence in order to ensure that the opponent does not become overpowering. 
The desire to dominate as opposed to reconciliate is something that Henry Kissinger (2014) has highlighted as the critical reason why peaceful solutions for developments in Ukraine have failed. In his criticism, he highlights not only Russia but also the West as the culprits in attributing Ukraine a passive role in its own development. While superpowers consider different components of power in their own plans and monitor their rivals, they objectify the role of smaller powers. In this case, Ukraine has become a pawn in the hands of greater powers.

Energy, just like any other aspect of the economy, serves the purpose of state interests and as such can be easily treated as a tool in order to achieve states' foreign policy goals. Scholars have argued that the strategic role of energy in contemporary economy makes it into a formidable weapon. (Smith Stegen, 2011)

Relying on the balance of power concept, the Kremlin witnessed Kyiv's turn to the West as a clear shift in East-West balance of power that should have been hindered. This was not just a military power shift, but also a change in the European energy scene. As it is a zero-sum game, any hesitation on the part of Russia would have resulted in a loss and caused a threat to its security.

Russian attempts to neutralize Ukrainian plans for energy independence (or even becoming a net exporter), as well as removing Kyiv from Gazprom's relations with Europe, served the geopolitical interest of Russia and ensured the sustainability of the weaponizable energy dependence of Europe. With all the different sanctions established on Russia, sanctioning energy trade has never been seriously on the table, demonstrating that the main export article of Russia still maintains its solid grip on the European energy market, enabling it to use energy as a weapon. The continued instability in Ukraine has also ensured that the significant energy reserves that could have provided a solid alternative, remain unused.

Mearsheimer states that Russian attempt to annex Crimea was a response to the West and especially NATO's enlargement to the East, and Putin "responded by taking Crimea, a peninsula he feared would host a NATO naval base, and working to destabilize Ukraine until it abandoned its efforts to join the West" (Mearsheimer, 2014). He also pointed to Geopolitics 101 which says that "great powers are always sensitive to potential threats near their home territory", which can be applied to explain Russia's actions (Toft, 2005). The implication of Moscow-Kyiv energy relation according to this perception results in subtractive Russian energy diplomacy about Ukraine, instead of an additive policy. This could mean that by annexing Crimea, Russia's first priority was to 
subtract the weight from the adversary scale rather than adding the weight to its own power. In other words, Russian energy diplomacy in the Ukraine crisis is similar to what 'wedge strategy' explains. According to this strategy, when a state attempts to prevent, break up, or weaken a threatening or blocking alliance at an acceptable cost, it reduces the number and strength of enemies organized against it (Crawford, 2011). Some implications prove Russia's 'subtractive' approach and its 'wedge strategy' from an energy perspective.

First, a pro-Western Ukraine could contribute to the EU's plans to reduce dependence on Russian gas in the future relying on its natural resources. In fact, following Kyiv's pivot to the West in the spring of 2014, Kremlin leaders came to the conclusion that if Ukraine wanted to join the Western Bloc it had to be an economically and strategically "weakened" Ukraine, which would be less threatening for Russia. This included the perspective of Russian energy dominance on the EU gas market as well. The destabilization of the Eastern Ukraine and annexation of Crimea would deprive the Ukraine government of taking advantage of these zones economically. This could suggest that Russia has destroyed the geo-economic value of Ukraine, undermining it as a perspective country to be integrated into Western institutions.

Second, Russia is not even able to take advantage of the existing energy potential of the Crimean Peninsula at the moment. Chornomornaftohaz, the nationalized former Ukrainian energy company in Crimea, has been sanctioned by the United States and the EU, bringing developments of Crimean resources into doubt in the near future. Moreover, production at the biggest Crimean gas field, Odesskoye, has been suspended as of July 1, 2018, because of an international maritime rights arbitration case initiated by Ukraine (Slav, 2018). Ukrainian government also accused Russia of an invasion into its national territory under Annex VII of the United Nation Convention of Law of the Sea UNCLOS (International Arbitration Resources, 2016). Russia cannot even take advantage of the annexed territorial waters of Crimea in order to lay down the TurkStream pipeline under the Black Sea bed, although it would be cheaper due to the lower depth of the sea in Crimean water. This could mean that while Russia does not take advantage of Crimean resources economically, the subtractive value of the annexation is more important for the Kremlin.

Third, Russia has been compelled to spend billions of rubles in Crimea to enhance Crimean energy infrastructures or to make it compatible with the Russian systems. For instance, Russia spent 47.3 billion rubles (approximately 750 million dollars) to connect Crimea's electricity network to its own after the network connection to Ukraine was cut (Nechepurenko \& MacFarquhar, 
2015). The planned undersea gas pipeline from Krasnodar to Crimea also needs a 300 million dollar investment. Generally, the Kremlin announced that it would dedicate 50 billion rubles for enhancement of Crimean energy security by 2020 (RIA-Novosti, 2016). The results of the analysis show that Russia has gained less than it has spent on energy in the Crimea and it shows that the "additive" approach does not apply here.

Fourth, the same subtractive approach to Ukraine has already been applied by Russia when it comes to Kyiv's role as a transit route for Russian gas. Traditionally, a major volume of Russian gas has been passed through Ukraine towards Europe, however, Russia started to bypass Ukraine with the construction of Nord Stream 1 and 2, and TurkStream. Many experts and politicians have severely criticized Nord Stream 2, relying on the claim that Europe does not need a new pipeline but renovation of the existing Ukrainian network will be adequate (Talus, 2019). Therefore, Nord Stream 2 is known as a political project in which Russia tries to annihilate the Ukrainian role and deny it from transit revenue (Pirani \& Yafimava, 2016). One may argue that the same approach can be seen in the case of Crimean energy resources - depriving Ukraine of energy resources has already been put on the agenda by the Kremlin.

The implication of this according to above-mentioned facts shows that impetus for the annexation of Crimea is strategical rather than economic. Despite the fact that the strategic value of Sevastopol has been discussed as the primary incentive for the Kremlin to annex the peninsula more widely (Biersacka \& O'Lear, 2014), it seems that Russian policy on this case was also subtractive. In fact, even when Russia wanted to extend Kharkiv Pact in 2014 to rent Sevastopol for the next 25 years (Government of Ukraine, 2010), some Duma members already claimed that Russia could establish a new port for itself on the coast of the Black Sea instead of extending Sevastopol's rental contract (Amirahmadian, 2015). Therefore, one could say that theKremlin's incentives to deny Ukraine Sevastopol was more important than achieving benefits of its own. As a result, the same can be argued from the energy perspective, since Russia has spent more than it has earned from the annexation of Crimea, from the energy perspective.

\section{Conclusion}

In this research, the role of Ukrainian energy resources in Russian plans for annexation of Crimea has been studied. Understanding the reasons behind the annexation is important especially when it comes to energy resources since 
Ukraine was expected to play an important role in the future of European energy perspective. Therefore, the study tried to explain the situation from an energy perspective relying on different facts and considering the principles of the realism school.

The results of the study show that the Kremlin saw Ukraine's pivot to the West as a loss for itself in a zero-sum game according to the balance of power concept. Therefore, Moscow attempted to prevent a sever change in the balance of power by diminishing the geo-economic value of Ukraine for the West in line with a subtractive approach. This could mean that depriving pro-Western Ukrainian government from the energy resources of the Black Sea was more important than seizing them in favor of Russia, especially taking into account the fact that Russia itself is rich enough in mineral resources, without needing Crimean resources. One may argue that Russia hindered an energy coalition against its dominance on the future European gas market. This has been achieved by the annexation of the Crimea as well as destabilization of Eastern Ukraine. The implication of this according to 'wedge strategy' is that energy resources of the Crimea and Eastern Ukraine should be taken into account in the annexation by Russia, in addition to the military values of the peninsula. Moreover, the results of the research show that Russia has spent hundreds of million dollars to develop Crimean energy infrastructures but instead, did not gain that much from these resources. This could suggest that Russia does not need the Crimean energy resources but instead, denying Ukraine these resources is a part of Russia's plan in the annexation of Crimea.

The research was done on the basis of energy statistics and data available from the very last years before the annexation of Crimea. After the seizure of the peninsula, the Russian federal government has not officially updated or published these statistics. Therefore, neither estimation about the economic values of these resources not Russia's future plans are available to elaborate on the topic. Future researches may be carried out relying on viable information on this and considering the latest implemented plans of Russia in this regard.

Javad Keypour is an early-stage researcher and a PhD student at the Tallinn Law School. He has worked for Iranian Vice Presidency for Science and Technology Office for five years as an expert on energy markets. He is also the editor-in-chief of The Energy Diplomacy Journal, published in Iran. Javad received his BA degree from the Tehran Polytechnic in 2008 and an MSc degree in 2011. His major research focus are EU-Russia energy relations, natural gas market analysis, and the Middle East politics. 
Ivar Hendla graduated with an MA degree in international relations from the Tallinn University of Technology (TalTech) in 2009. Subsequently, he was engaged as a lecturer in the Department of International Relations at TalTech until 2018. Since then, he is an advisor in the Government Office of Estonia Strategy Unit. Ivar Hendla is also a doctoral researcher at the University of Tampere. His main research interests include theories of international relations, public opinion, and foreign policy development in small states.

\section{References}

Amirahmadian, B. (2015), 'Russia would not be as the West for Iran,' The Energy Diplomacy, 19 March, pp. 118-121.

Astrov, A. (2011), The Great Power (Mis) Management, Surrey: Ashgate Publishing.

Biersacka, J. \& O'Lear, S. (2014), 'The geopolitics of Russia's annexation of Crimea: narratives, identity, silences, and energy,' Eurasian Geography and Economics, vol. 55, no. 3, pp. 247-269. https://doi.org/10.1080/15387216.2014.985241

BP (2017), BP Statistical Review of World Energy 2017, London: BP.

Clark, I. (2009), 'Bringing hegemony back in: the United States and international order,' International Affairs, vol. 85, no. 1, pp. 23-36. https://doi.org/10.1111/j.1468-2346.2009.00778.x

Colgan, J. D. \& Van de Graaf, T (2017), 'Russian gas games or well-oiled conflict? Energy security and the 2014 Ukraine crisis,' Energy Research \& Social Science, vol. 24, pp. 59-64. https://doi.org/10.1016/j.erss.2016.12.018

Crawford, T. W. (2011), 'Preventing enemy coalitions,' International Security, vol. 11, no. 4, pp. 155-189. https://doi.org/10.1162/ISEC_a_00036

EEAS (2018), 'EU and Ukraine sign $€ 50$ million agreement to support Energy Efficiency Fund,' 18 April. Retrieved from https://eeas.europa.eu/delegations/ukraine/43125/ eu-and-ukraine-sign-\%E2\%82\%AC50-million-agreement-support-energyefficiency-fund_en [accessed 3 Jun 2018]

EIA (2015), Technically Recoverable Shale Oil and Shale Gas Resources: Other Eastern Europe, Washington, DC: US Department of Energy. Retrieved from https:// www.eia.gov/analysis/studies/worldshalegas/pdf/Eastern_Europe_BULGARIA_ ROMANIA_UKRAINE_2013.pdf [accessed 19 Nov 2019]

EIA (2017), Ukraine Country Analysis Brief. Retrieved from https://www.eia.gov/beta/ international/analysis.php?iso=UKR [accessed 3 Jun 2018]

EIA (2018), Country Analysis Brief: Russia, Washington, DC: US Energy Information Administration.

Eurasian Business Briefing (2016), 'Crimea's oil and gas assets,' 20 October. Retrieved from https://www.eurasianbusinessbriefing.com/naftogaz-sues-russia-2-6bn/ crimeas-oil-and-gas-assets-platts-chomomornaftogaz/ [accessed 16 Jun 2019] 
Eurostat (2019), 'Energy import dependency by products.' Retrieved from https:// ec.europa.eu/eurostat $/ \operatorname{tgm} /$ refreshTableAction.do?tab=table\&plugin $=1 \& p \operatorname{pode}=\mathrm{s}$ dg_07_50\&language $=$ en [accessed 16 Jun 2019]

Favasuli, S. (2017), 'Ukraine eyes gas exports by 2020,' Interfax Global Energy, 11 May. Retrieved from http://interfaxenergy.com/gasdaily/article/25862/ukraineeyes-gas-exports-by-2020 [accessed 2 Jun 2018]

Government of Ukraine (2010), Uhoda mizh Ukrayinoyu ta Rosijskoyu Federaciyeyu z pytan perebuvannya Chornomorskoho flotu Rosijskoyi Federaciyi na terytoriyi Ukrayiny [Agreement between Ukraine and the Russian Federation on the stay of the Black Sea Fleet of the Russian Federation on the territory of Ukraine], Government of Ukraine, 27.4.2010. Retrieved from http://zakon4.rada.gov.ua/ laws/show/643_359 [accessed 21 Apr 2018]

Guest, G.; MacQueen, K. M. \& Namey, E. E. (2012), Applied Thematic Analysis, California: SAGE. https://doi.org/10.4135/9781483384436

Hall, M. (2018), Norwegian Gas Exports: Assessment of Resources and Supply to 2035, Oxford: Oxford Institute for Energy Studies. https://doi. org/10.26889/9781784671037

Henderson, J. (2015), 'Russia's changing gas relationship with Europe,' Russian Analytical Digest, no. 163, pp. 2-6.

IES (2010), Energy Strategy of Russia, Moscow: Institute of Energy Strategy.

International Arbitration Resources (2016), 'Arbitration against Russia arising out of the annexation of Crimea.' Retrieved from https://www.international-arbitrationattorney.com/new-arbitration-russia-arising-annexation-crimea/ [accessed 4 Jun 2018]

Kabyshev, B.; Krivchenkov, B.; Stovba, S. \& Ziegler, P. (1998), 'Hydrocarbon habitat of the Dniepr-Donets Depression,' Marine and Petroleum Geology, vol. 15, no. 1, pp. 177-190. https://doi.org/10.1016/S0264-8172(98)00018-X

Karagiannis, E. (2014), 'The Russian interventions in South Ossetia and Crimea compared: military performance, legitimacy and goals,' Contemporary Security Policy, vol. 35, no. 3, pp. 400-420. https://doi.org/10.1080/13523260.2014.963 965

Kissinger, H. (2014), 'To settle the Ukraine crisis, start at the end,' The Washington Post, 5 March.

Kramer, M. (2002), 'NATO, the Baltic States and Russia: a framework for sustainable enlargement,' International Affairs, vol. 78, no. 4, pp. 731-756. https://doi. org/10.1111/1468-2346.00277

Lockwood, D. (1993), 'Ukraine's position hardens despite some positive signs,' Arms Control Today, vol. 23, no. 7, pp. 25-30.

Mearsheimer, J. J. (2001), The Tragedy of Great Power Politics, New York \& London: W. W. Norton \& Company. 
Mearsheimer, J. J. (2014), 'Why the Ukraine crisis is the West's fault: the liberal delusions that provoked Putin,' Foreign Affairs, vol. 93, no. 5, pp. 77-84.

Nechepurenko, I. \& MacFarquhar, N. (2015), 'As sabotage blacks out Crimea, Tatars prevent repairs,' The New York Times, 24 November. Retrieved from https://www. nytimes.com/2015/11/24/world/europe/crimea-tatar-power-lines-ukraine.html [accessed 23 Jun 2018]

Nord Stream 2 (2018), 'Shareholder and financial investors,' Nord Stream 2. Retrieved from https://www.nord-stream2.com/company/shareholder-and-financial-investors/ [accessed 2 Jun 2018]

Pirani, S. \& Yafimava, K. (2016), Russian Gas Transit Across Ukraine Post-2019: Pipeline Scenarios, Gas Flow Consequences, and Regulatory Constraints, Oxford: Oxford Institute for Energy Studies. https://doi.org/10.26889/9781784670542

Polityuk, P. (2012), 'Exxon, Shell-led group win \$10 billion Ukraine gas project,' Reuters, 15 August. Retrieved from https:/www.reuters.com/article/us-shellexxonmobil-ukraine/exxon-shell-led-group-win-10-billion-ukraine-gas-projectidUSBRE87E0C320120815 [accessed 3 Jun 2018]

Polityuk, P. \& Balmforth, R. (2013), Ukraine signs \$10 billion shale gas deal with Chevron,'Reuters, 5 November. Retrieved from https://www.reuters.com/article/ us-ukraine-chevron/ukraine-signs-10-billion-shale-gas-deal-with-chevronidUSBRE9A40ML20131105 [accessed 2 Jun 2018]

RIA Novosti Krym (2016), 'Putin: u Kryma posle zapuska energomosta budet moshchnost' 1,27 tysiach MVt' [Putin: the Crimea after the launch of the energy bridge will have a capacity of 1.27 thousand MW], 11 May. Retrieved from https:/crimea.ria. $\mathrm{ru} /$ society/20160511/1104917225.html [accessed 3 Jun 2018]

Schwartz, P. N. (2014), 'Crimea's strategic value to Russia' [blog], Center for Strategic and International Studies, 18 March. Retrieved from https://www.csis.org/blogs/ post-soviet-post/crimeas-strategic-value-russia [accessed 21 Apr 2018]

Slav, I. (2018), 'Russia may explore Crimea gas resources,' Oilprice. Retrieved from https://oilprice.com/Latest-Energy-News/World-News/Russia-May-ExploreCrimea-Gas-Resources.html [accessed 2 Jun 2018]

Smith Stegen, K. (2011), 'Deconstructing the "energy weapon": Russia's threat to Europe as case study,' Energy Policy, vol. 39, no. 10, pp. 6505-6513. https://doi. org/10.1016/j.enpol.2011.07.051

Soldatkin, V. (2018), 'Gazprom says gas transit via Ukraine to Europe may fall to 10-15 bcm per year,' Reuters, 10 April. Retrieved from https:/www.reuters.com/article/ us-russia-ukraine-gas/gazprom-says-gas-transit-via-ukraine-to-europe-may-fallto-10-15-bcm-per-year-idUSKBN1HH2HL [accessed 2 Jun 2018]

Stavytskyi, E. (2013), 'Only owing to Yuzivska gas field the production of shale gas can be increased in 2 times,' Government portal: Web portal of Ukraine government, 
30 January. Retrieved from http://old.kmu.gov.ua/kmu/control/en/publish/ printable_article?art_id=246008470 [accessed 2 Jun 2018]

Talus, K. (2019), 'EU gas market amendment - despite of compromise, problems remain,' Oil, Gas \& Energy Law, vol. 2, pp. 1-12.

TASS (2014), 'Minister charts Crimea potential for hydrocarbon riches,' 15 April. Retrieved from http://tass.com/economy/727905 [accessed 21 Apr 2018]

Tawonezvi, J. (2017), 'The legal and regulatory framework for the EU shale gas exploration and production regulating public health and environmental impacts,' Energy, Ecology and Environment, vol. 2, no. 1, pp. 1-28.

https://doi.org/10.1007/s40974-016-0044-5

The World Bank (n.d.), [Home page]. Retrieved from http://www.worldbank.org [accessed 19 Nov 2019]

Toft, P. (2005), 'John J. Mearsheimer: an offensive realist between geopolitics and power,' Journal of International Relations and Development, vol. 8, no. 4, pp. 381-408. https://doi.org/10.1057/palgrave.jird.1800065

UAWire (2018), 'Russia will stop production at the main gas field in Crimea because of the legal case brought by Ukraine,' 16 February. Retrieved from http://www. uawire.org/russia-will-stop-production-at-the-main-gas-field-in-the-crimeabecause-of-the-legal-case-brought-by-ukraine\# [accessed 4 Jun 2018]

Walt, S. (1985), 'Alliance formation and the balance of world power,' International Security, vol. 9, no. 4, pp. 3-43. https://doi.org/10.2307/2538540

Waltz, K. (1979), Theory of International Politics, Long Grove, IL: Waveland Press.

Weijermars, R. (2013), 'Economic appraisal of shale gas plays in Continental Europe,' Applied Energy, vol. 106, pp. 100-115.

https://doi.org/10.1016/j.apenergy.2013.01.025

Wilson, J. L. (2010), 'The legacy of the color revolutions for Russian politics and foreign policy,' Problems of Post-Communism, vol. 57, no. 2, pp. 21-36. https:// doi.org/10.2753/PPC1075-8216570202 